Marga Živitere and Viktors Člaidze

\title{
Legal environment, national strategies and policies for the employment of people with disabilities
}

\begin{abstract}
This article explores the changes in European disability policy since the European Year of People with Disabilities in 2003, when the Information Systems Management Institute (in Riga) developed a study course on the Employment of People with Disabilities for business administration students, managers and entrepreneurs. Drawing on the experience of developing this study course further, two of its interlinked modules, European Strategies and Policies on the one hand and Legal Environment, National Strategies and Policies on the other, are analysed. The article cites the United Nations Convention on the Rights of People with Disabilities (2007) and the Decision by the Council of the European Union Concerning the Conclusion, by the European Community, of the United Nations Convention on the Rights of Persons with Disabilities (2009) as turning points. It then goes on to look at a cross-section of different levels local and global, national and supranational - regarding national and European disability strategies in general and, in particular, at the ways in which they deal with the employment of people with disabilities.
\end{abstract}

Keywords: employment, EU, Latvia, legislation, people with disabilities

Introduction

When news of the ratification by Latvia on 1 March 2010 of the United Nations Convention on the Rights of Persons with Disabilities, and of its entering into force in Latvia on 31 March 2010, reached people with disabilities in Latvia, it was greeted as a historic moment which will bring about positive change (see the website of SUSTENTO - the Latvian Umbrella Body for Disability Organisations). Urged on by the Decision of the Council of the European Union (Council of the European Union, 2010) on the one hand, and by SUSTENTO (Anča, nd) on the other, the government of Latvia passed a law On the United Nations Convention on the Rights of Persons with Disabilities (VSIA 'Latvijas Vēstnesis', nd) and adopted the Action Plan for Implementation of the Convention 2010-2012 (Labklājības Ministrija, 2010).

This story of signing, ratification and the entering into force of a convention, and the passing of a law and an implementation plan (for the first stage) in one European Union country (Latvia), shows the complexity of disability issues at different levels of policy: the national; the European or supranational (Waldschmidt, 2009); and the global policy regime against the background of the United Nations Convention on the Rights of Persons with Disabilities (Priestley, 2007). It also shows the important role of organisations for people with disabilities which actively take part in and influence dis- 
ability policy at all levels. Colin Barnes and Alison Sheldon, following the research carried out by Rachel Hurst and Bill Albert (2006), stress that:

Disabled people's organisations working together as the International Disability Caucus (IDC) were an active partner in developing and promoting the Convention on the Rights of Persons with Disabilities... adopted by the UN General Assembly. (Barnes and Sheldon, 2010: 778)

They draw attention to the interrelated issues of disability and poverty, especially in low- and middle-income states, and argue that poverty is best understood as a complex matrix of social exclusion since such indicators as:

Poverty lines are country specific and most countries have different ideas of what constitutes a minimum standard of living. (Barnes and Sheldon, 2010: 774)

We would agree that poverty is best understood as a complex matrix of social exclusion, but the available (although incomplete) research data in Latvia into poverty and social exclusion indicators, for example, also deliver some insight into this complex problem. According to comparable data from the Community Survey on Income and Living Conditions (EU-SILC) in EU member states in 2007:

In the European Union generally Latvia is characterised with the highest at-risk-of-poverty rate. In the meantime, the at-risk-of-poverty threshold in Latvia is the seventh lowest and it is exceeded in this indicator not only by Romania and Bulgaria, but also by Poland, Lithuania, Hungary and Slovakia. (Latvijas Statistika, 2008)

The inter-related issues of disability and poverty in low- and middle-income states result in disability support systems being under-resourced. Thus, some experts may well state that:

The predominant policy approach in Latvia is the mainstreaming model. (Calite, 2009)

However, the lack of resources, the difficult economic situation in Latvia affecting state-financed rehabilitation programmes for people with disabilities, and the growth of the unemployment rate in general and also among people with disabilities (Calite, 2009) but, above all, issues to do with the:

Accessibility of workplaces, technologies and supporting infrastructure (Greve, 2009)

do cast doubt on the success of a mainstreaming disability policy in Latvia. Nevertheless, the Decision of the Council of the European Union on the United Nations Convention on the Rights of Persons with Disabilities, as well as the signing and ratification of this Convention by the states of the European Union and the European Disability Strategy 2010-2020 (European Commission, 2010a) aiming at a barrier-free 
Europe, provides not only legal and practical frameworks but also a common basis for analysis among these frameworks.

In this article, the authors explore the issue of the employment of people with disabilities by focusing on the legal environment, national strategies and policies as important themes within the study course for students of business administration, managers and entrepreneurs, while adopting the social model of disability in general and, in particular, an approach firmly rooted within equal rights. The authors draw on experiences gained in developing the study course Employment of People with Disabilities within the Leonardo da Vinci project Ability not Disability in Employment (2003-2005) (Fissamber et al, 2005; Ivanova et al, 2005; Živitere, 2005), followed by work on two transfers of innovation projects stemming from Ability not Disability in Employment within the same Leonardo da Vinci framework (firstly, Increasing the Employability of Disabled People (2007-2009) (Coskun et al, 2009a, 2009b); and, secondly, Ability not Disability in the Workplace (2009-2011) (Information Systems Management Institute, nd). Additionally, the authors also draw on participation in the Leonardo da Vinci project PwD Employ - Personal Learning Environment for the Efficient Recruitment of People with Disabilities (2008-2010) (PWD Employ Partnership, nd). The authors discuss the problems they encountered, mostly as a result of the lack of comparability of data from different EU countries and Turkey, and the different research models adopted by researchers, social partners, policy-makers and so on; as well as the new basis for collaboration and understanding opened up by the paradigm shift at all levels of disability policy: local; global; national; and supranational.

The employment of people with disabilities

The European Disability Strategy 2010-2020: A Renewed Commitment to a Barrier-Free Europe states that:

One in six people in the European Union (EU) has a disability that ranges from mild to severe making around 80 million who are often prevented from taking part fully in society and the economy because of environmental and attitudinal barriers. For people with disabilities the rate of poverty is $70 \%$ higher than the average partly due to limited access to employment. Over a third of people aged over 75 have disabilities that restrict them to some extent, and over $20 \%$ are considerably restricted. Furthermore, these numbers are set to rise as the EU's population ages. The EU and its Member States have a strong mandate to improve the social and economic situation of people with disabilities. (European Commission 2010a: 3)

Within this strategy, employment is mentioned as one of eight main areas of action and it is stressed that EU action is designed to:

Enable many more people with disabilities to earn their living on the open labour market (European Commission, 2010a: 7)

In the related document, the United Nations Convention on the Rights of Persons with Disabilities, which is attached as Annex I in the Decision of the Council of the European Union, it is made clear that: 
States Parties recognise the right of persons with disabilities to work, on an equal basis with others; this includes the right to the opportunity to gain a living by work freely chosen or accepted in a labour market and work environment that is open, inclusive and accessible to persons with disabilities. (Council of the European Union, 2010: 47).

Both these documents are based on the rights approach and recognise the right of people with disabilities to enter the open labour market. When the team of researchers at the Information Systems Management Institute proposed the project Ability not Disability in Employment (AnDE) within the Leonardo da Vinci framework in 2003, the main idea was to raise awareness among business administration students, managers and entrepreneurs - that is, employers and future employers - of the skills, merits and abilities of people with disabilities and to foster an attitude of respect for the rights of people with disabilities. Considering two equally important events and processes for Latvia in this regard - the European Year of People with Disabilities (2003) and the country's accession to the European Union (2004) - the researchers decided that two of the four modules of the study course Employment of People with Disabilities should be devoted to European Policies to Promote Employment and Social Inclusion (module 2) (Fissamber et al, 2005; PWD Employ Partnership); and to the Possibilities for Employers to Co-operate with Educational and Governmental Institutions, Employment Agencies and Social Organisations (module 4) (Ivanova et al, 2005) (which later became module 3: Legal Environment, National Strategies and Policies (PWD Employ Partnership).

Different levels, such as the national and the supranational (European), the local and the global, do intertwine, as was emphasised already in the introduction to this article but, for educational purposes, it was - and, we believe, still is - useful to divide the material into separate modules or chapters. That such an approach is reasonable is shown by recent research: for example, by Anne Waldschmidt (2009), who first analyses and compares European social and disability policies as they have evolved; and then distinguishes three different welfare state regimes, first as ideal types and then as real states: the liberal (the UK); the conservative (Austria, Germany, France, Italy); and the social democratic (Sweden, Norway). She also stresses that:

One should be aware that there is no real existing welfare state that is actually congruent to one of these three ideal models,

and that, in fact:

Each empirical welfare regime represents a 'system mix'. (Waldschmidt, 2009: 19)

However, this scheme does help us to understand some of the dynamics operating in different European countries. By taking into account recent developments within European disability policy, we would also propose for consideration the usefulness of the third module of the course Employment of People with Disabilities where, alongside the modules European Policies to Promote Employment and Social Inclusion and Legal Environment, National Strategies and Policies, there is the module National Strategies 
to Implement the United Nations Convention on the Rights of Persons with Disabilities. This would show the local, global, national and supranational levels intertwined and in action. The importance of such a cross-sectional approach is demonstrated by the reports of the Disability High Level Group (three annual reports thus far) on the Implementation of the UN Convention on the Rights of Persons with Disabilities (European Commission, 2008, 2009, 2010b).

Employment of people with disabilities: European strategies and policies

In researching disability policies in the European Union over the last five decades, and analysing documents published by EU authorities between 1958 and 2005, Anne Waldschmidt has found that:

As disability policy has its origin in social policy it makes sense to study possible links between welfare concepts and disability policy approaches. (Waldschmidt, 2009: 10)

It is especially important to compare and analyse both welfare and disability policy approaches due to it having taken the EU:

Nearly 20 years after its start in 1957 to publish the first document that can be considered as explicitly relevant for disabled people: on June 27, 1974, the Council issued the 'Resolution ... establishing the initial Community action programme for the vocational rehabilitation of handicapped persons'. (Waldschmidt, 2009: 16)

Waldschmidt also points to the need to understand the:

Backlog in disability policy from [1980 until 1986] which corresponds with a general stagnation in social policy. (Waldschmidt, 2009: 16)

She has also found that, from the 1970s up to the middle of the 1990s, European disability policy:

Was geared towards the labour market integration of disabled people, (Waldschmidt, 2009: 11)

in parallel with European social policy, which was aimed:

At better working conditions and more democracy in business and companies. (Waldschmidt, 2009: 17)

She concludes that:

At the early stage of EU disability policy, from 1974 until 1986, employment issues were of most importance; in recent years, starting with the activities of the Commission in 1996, the civil rights approach proves to be the prominent topic on the EU disability agenda. (Waldschmidt, 2009: 16). 
One might gain the impression that she is describing successive stages; however, the main tendency in European disability policies is to become more inclusive. Thus, for example, employment issues have become part of the rights approach, i.e. as a right to work. Waldschmidt's research reaches only up to 2005, while we are in a position to extend this up to 2011, considering two events which are especially relevant: the UN Convention on the Rights of Persons with Disabilities (2007); and the Council Decision Concerning the Conclusion, by the European Community, of the United Nations Convention on the Rights of Persons with Disabilities (2009).

In sum, we agree with Waldschmidt that:

The development of EU disability policy closely corresponds to the ups and downs of general social policy at the European level, (Waldschmidt, 2009: 17)

but, at the same time, there are also differences. Waldschmidt distinguishes seven phases in European social policy and five phases in European disability policy, the latter ending in 2003 with the European Year of People with Disabilities. By taking Waldschmidt's schema as a basis (Table 1), we may thus add two more phases to European disability policy: the UN Convention on the Rights of Persons with Disabilities (2007) as another global impulse (Waldschmidt stresses the importance of the International Year of the Disabled, declared by the United Nations (in 1981) as a stimulus for the third phase of European disability policy); and the Council Decision Concerning the Conclusion, by the European Community, of the United Nations Convention on the Rights of Persons with Disabilities (2009). This latter radically changes the idea of national, supranational (European) and global strategies, since each member state has to present national implementation strategies as regards the UN Convention (European Commission, 2008, 2009, 2010b).

Table 1 - European social policy and disability policy in comparison

\begin{tabular}{|c|c|c|}
\hline $\begin{array}{l}\text { Periods of the } \\
\text { EC/EU }\end{array}$ & Social policy of the EC/EU & Disability policy of the EC/EU \\
\hline $1958-1973$ & $\begin{array}{l}\text { (1) Social policy exists only at a very low } \\
\text { level }\end{array}$ & \\
\hline 1974-1979 & $\begin{array}{l}\text { (2) The first action programme in social } \\
\text { policy is started }\end{array}$ & $\begin{array}{l}\text { (1) First action programme with regard to } \\
\text { people with disabilities, focusing on } \\
\text { vocational rehabilitation }\end{array}$ \\
\hline 1980-1986 & $\begin{array}{l}\text { (3) British veto leads to general stagnation in } \\
\text { social policy }\end{array}$ & $\begin{array}{l}\text { (2) Stagnation in disability policy; impulses } \\
\text { from global disability policy }\end{array}$ \\
\hline 1986-1997 & $\begin{array}{l}\text { (4) 1986-1992: EC becomes an actor in } \\
\text { social policy } \\
\text { (5) 1993-1997: Treaty of Maastricht creates } \\
\text { new rules }\end{array}$ & $\begin{array}{l}\text { (3) 1986-1995: Increased actions in the area } \\
\text { of labour market integration }\end{array}$ \\
\hline
\end{tabular}




\begin{tabular}{|l|l|l|}
\hline 1998-2000 & $\begin{array}{l}\text { (6) 1998-2000: The social policy agenda is } \\
\text { consolidated; the right to non-discrimination } \\
\text { is put on the EU agenda }\end{array}$ & $\begin{array}{l}\text { (4) 1996-2000: New orientation in } \\
\text { European disability policy: shifting from } \\
\text { vocational rehabilitation to equal rights }\end{array}$ \\
\hline 2000-2009 & $\begin{array}{l}\text { (7) Common aims for social policy and } \\
\text { equalisation policy issues are formulated }\end{array}$ & $\begin{array}{l}\text { (5) Non-discrimination policy is } \\
\text { implemented; the European Year of People } \\
\text { with Disabilities (2003) provides additional } \\
\text { impulses } \\
\text { (6) Impulses from global disability policy: } \\
\text { the United Nations Convention on the } \\
\text { Rights of Persons with Disabilities (2007) }\end{array}$ \\
\hline After 2009 & $\begin{array}{l}\text { (7) Council of the European Union: } \\
\text { Decision of 26 November 2009 Concerning } \\
\text { the Conclusion, by the European } \\
\text { Community, of the United Nations } \\
\text { Convention on the Rights of Persons with } \\
\text { Disabilities }\end{array}$ \\
\hline
\end{tabular}

Source: Adapted from Waldschmidt (2009): 18.

In comparing European social and disability policies, Waldschmidt names the UK as a significant actor when, from 1980 to 1985 :

Due to the strictly liberal economic approach of Prime Minister Margaret Thatcher all concrete social policy initiatives of the Commission met the British veto. At this time, decisions by majority vote were not yet possible in the EU; for this reason any social policy at all came to a standstill. (Waldschmidt, 2009: 17)

Correspondingly, the same years saw a backlog in disability policy, with the only changes coming from global impulses such as the International Year of the Disabled declared by the United Nations (taking place in 1981). However, these global impulses - for example, on equal rights - could also be seen as originating in specific welfare regimes, as exemplified by the Scandinavian countries such as Sweden or Norway. Therefore, Waldschmidt emphasises that it is also important to see the context as constituting:

Three dimensions of disability policy, i.e., social protection, labour market integration and equal rights [as a] matrix that combines the three classical types of welfare regimes (Waldschmidt, 2009: 11).

The employment of people with disabilities: legal environment, national strategies and policies

Drawing on the welfare state typology developed by Esping-Andersen (1990), Waldschmidt creates a matrix that combines the three classical types of welfare regimes and the different disability policy approaches associated with them (see Table 2). She argues: 
It is very likely that different welfare regimes which are applied in different member states are present at the European level as well. The presumption is that due to bottom-up effects one model or a specific combination of different models will turn out dominant at the supranational level as well. (Waldschmidt, 2009: 11)

And vice versa: top-down effects are present at the national level, especially after 2009.

Table 2 - Disability policy in different welfare regimes

\begin{tabular}{|l|c|c|c|}
\hline Welfare regime & Liberal & Conservative & $\begin{array}{c}\text { Social } \\
\text { Democratic }\end{array}$ \\
\hline Social protection & $\mathrm{X}$ & $\mathrm{XX}$ & $\mathrm{XXX}$ \\
\hline Integration into the labour market & $\mathrm{XX}$ & $\mathrm{XXX}$ & $\mathrm{X}$ \\
\hline Civil rights & $\mathrm{XXX}$ & $\mathrm{X}$ & $\mathrm{XX}$ \\
\hline
\end{tabular}

Source: Waldschmidt (2009): 20 .

A liberal welfare regime is focused on the market; thus, social protection:

In terms of granting a minimum living wage will be in operation. (Waldschmidt, 2009: 20, emphasis added).

She assumes further that:

It is probable that [special] schemes for job market integration will comparatively seldom be applied, since they are rated as interfering with the forces of the free market. (Waldschmidt, 2009: 20)

Paradoxically, civil rights in the form of a non-discrimination policy:

Will strongly be represented, since it aims at providing free and equal access to the market for all individuals so that they are able to supply themselves. (Waldschmidt, 2009: 20)

However, according to this model or regime, only specific civil rights - as opposed to equal rights - are taken into account, gearing towards the labour market integration of disabled people (an example of European disability policy from the 1970s up to the middle of the 1990s).

In 2003, the Information Systems Management Institute embarked on the Ability not Disability in Employment project with the Exchange Network for Training and Enterprise from Birmingham, UK, as a partner institute. The matrix helps us better understand not only the liberal welfare regime in general, but also many initiatives and good practices offered by our British partner in particular, as well as different European policies at the supranational level. 
In contrast to the liberal approach, in conservative, or conservative-corporatist, welfare regimes:

Civil rights will only be of minor value.

Instead,

A strong accentuation of labour market integration is very likely, since in conservative social policy social insurance-based schemes heavily rely on individuals' participation in the labour market. (Waldschmidt, 2009: 20)

People with disabilities in such conservative regimes would be socially protected at the basic level. Some knowledge of conservative-corporatist welfare regimes can help us improve our understanding not only of the different processes going on in Austria, Germany, France or Italy, but also of the relevant policies at the European level.

With regard to the social democratic welfare model, also known as the universalist model,

It is probable that basic social care systems are of high importance, whereas measures of job market integration will be weaker. One can also conclude that civil rights and non-discrimination policies are of middle relevance: on the one hand, they are compatible with this welfare regime's orientation towards social solidarity; on the other hand, the universalistic approach can foster the assumption that there is no need for civil rights given the high level of social rights. In short, the assumption is that, in this welfare model, social solidarity has a higher importance than individualist civil rights. (Waldschmidt, 2009: 20)

Illuminating as it is concerning the processes going on in Scandinavian countries, one should not forget about the differences between social rights, civil rights and equal rights.

Employment of people with disabilities: national strategies by European Union member states to implement the UN Convention

Working within the European framework of different Leonardo da Vinci projects since 2003, we can see the requirement, time and time again, of having to face up to the problem of the lack of comparability not only of the situation of people with disabilities in different member (and candidate) countries of the European Union but also of the definitions, data, policies, strategies and so on which are in use. By making the UN Convention the cornerstone of European disability policy since 2007, one can expect fundamental changes, as the annual reports on the implementation of the Convention (European Commission, 2008, 2009, 2010b) show. We are sure that the paths opened up by these significant events and research studies will lead to valuable insights into the dynamics of the local and global, the national and supranational; into a better 
understanding of complex issues; and, simply, into a better life not only for people with disabilities but for all of us.

\section{Conclusion}

Disability policies and strategies at different levels - local, global, national and European or supranational - have undergone major changes; however, only recent events - the United Nations Convention on the Rights of Persons with Disabilities (2007) and the adoption of this document as a basis for national strategies within the European Union - could be characterised as causing a paradigm shift. Based on the equal rights approach, among them the right of people with disabilities to work, such events stress the importance of mainstreaming disability issues. Drawing on our experience of developing study courses on the employment of people with disabilities for business students, managers and entrepreneurs - i.e. employers and future employers - within the European framework of Leonardo da Vinci projects, we have identified some of the problems that may be encountered, such as the lack of comparability of both data and definitions. Additionally, we can pinpoint the fundamental changes undergone not only by Latvia (via accession to the European Union in 2004 for example) but also by policy-makers at the European level, thus opening up new ways of understanding not only the national and supranational levels, but also the local and global ones.

\section{References}

Barnes, Colin and Alison Sheldon (2010) 'Disability, Politics and Poverty in a Majority World Context' Disability \& Society 25(7): 771-782.

Calite, Daina (2009) Report on the Employment of Disabled People in European Countries: Latvia Academic Network of European Disability Experts (ANED), November, 14 pp, available at: http://www.disability-europe.net [last accessed 12 January 2011].

Coskun, Recai, Marga Živitere, Svetlana Alexandrova, Seyhan Firat and Mahmut Hiziroglu (Eds.) (2009a) Disabled People and Employability (Distance Education Course designed within the Leonardo da Vinci project Increasing Employability of Disabled People) Sakarya (Turkey): Sakarya University, 273 pp.

Coskun, Recai, Marga Živitere, Svetlana Alexandrova, Seyhan Firat and Mahmut Hiziroglu (Eds.) (2009b) Disabled People and Employability (Handbook for Employers designed within the Leonardo da Vinci project Increasing Employability of Disabled People) Sakarya (Turkey): Sakarya University, 268 pp.

Esping-Andersen, Gøsta (1990) The Three Worlds of Capitalism Princeton, New Jersey: Princeton University Press, 260 pp.

Fissamber, Valter, Alexis Isaakidis and Anna Koniotaki (2005) 'European Policies to Promote Employment and Social Inclusion' in Marga Živitere (Ed.) (Terence Pugh (English Ed.)) Employment of People with Disabilities (Distance Education Course designed within the Leonardo da Vinci project Ability not Disability in Employment) Riga: Information Systems Management Institute, pp. 19-58. 
Greve, Bent (2009) The Labour Market Situation of Disabled People in European Countries and Implementation of Employment Policies: A Summary of Evidence from Country Reports and Research Studies Academic Network of European Disability Experts (ANED), April, 47 pp, available at: http://www.disability-europe.net [last accessed 12 January 2011].

Hurst, Rachel and Bill Albert (2006) 'The Social Model of Disability, Human Rights and Development Cooperation' in Bill Albert (Ed.) In or Out of the Mainstream? Lessons from Research on Disability and Development Cooperation Leeds: The Disability Press, pp. 24-39.

Ivanova, Ilze, Terence Pugh and Liene Zvirble (2005) 'The Possibilities for Employers to Co-operate with Educational, Governmental Institutions, Employment Agencies and Social Organizations' in Marga Živitere (Ed.) (Terence Pugh (English Ed.)) Employment of People with Disabilities (Distance Education Course designed within the Leonardo da Vinci project Ability not Disability in Employment) Riga: Information Systems Management Institute, pp. 138-170.

Priestley, Mark (2007) 'In Search of European Disability Policy: Between National and Global' ALTER - European Journal of Disability Research / Revue Européenne de Recherche sur le Handicap 1(1): 61-74.

Waldschmidt, Anne (2009) 'Disability Policy of the European Union: The Supranational Level' ALTER - European Journal of Disability Research / Revue Européenne de Recherche sur le Handicap 3(1): 8-23.

Živitere, Marga (Ed.) (2005) (Terence Pugh (English Ed.)) Employment of People with Disabilities (Handbook for Employers designed within the Leonardo da Vinci project Ability not Disability in Employment) Riga: Information Systems Management Institute, $64 \mathrm{pp}$.

Council of the European Union (2010) Council Decision of 26 November 2009 Concerning the Conclusion, by the European Community, of the United Nations Convention on the Rights of Persons with Disabilities (2010/48/EC) Official Journal of the European Union L23, Vol. 53, 27 January, pp. 35-61.

European Commission (2008) First Disability High Level Group Report on Implementation of the UN Convention on the Rights of Persons with Disabilities Brussels, 49 pp, available at:

http://ec.europa.eu/social/BlobServlet?docId=2293\&langId=en [last accessed 7 January 2011].

European Commission (2009) Second Disability High Level Group Report on Implementation of the UN Convention on the Rights of Persons with Disabilities Brussels, June, $242 \mathrm{pp}$, available at:

http://ec.europa.eu/social/BlobServlet?docId=2790\&langId=en [last accessed 7 January 2011]. 
European Commission (2010a) European Disability Strategy 2010-2020: A Renewed Commitment to a Barrier-Free Europe (Communication from the Commission to the European Parliament, the Council, the European Economic and Social Committee and the Committee of the Regions) Brussels, 15 November, $11 \mathrm{pp}$, available at: http://eur-lex.europa.eu [last accessed 27 January 2011].

European Commission (2010b) Draft Third Disability High Level Group Report on Implementation of the UN Convention on the Rights of Persons with Disabilities Brussels, March, 120 pp, available at:

http://ec.europa.eu/social/BlobServlet?docId=5070\&langId=en [last accessed 7 January 2011].

Labklājības Ministrija (2010) (LMPl_080609) Apvienoto Nāciju Organizācijas Konvencijas par personu ar invaliditāti tiesībām īstenošanas pasākumu plāns 2010.-2012.gadam available at: http://polsis.mk.gov.lv/view.do?id=3196 [last accessed 12 January 2011].

VSIA 'Latvijas Vēstnesis' (nd) Likums 'Par Konvenciju par personu ar invaliditāti tiesībām' Rīgā, 2010.gada 17.februārī, available at: http://www.likumi.lv/doc.php? $\underline{\mathrm{id}=205248}$ [last accessed 3 December 2010].

Anča, Gunta (nd) 'Svaru kausā likta cilvēka cieņa' ANO konvencija Rīga: Latvijas Cilvēku ar īpašām vajadzībām sadarbības organizācija SUSTENTO, available at: http://www.sustento.lv/resource/show/402 [last accessed 12 January 2011].

Information Systems Management Institute (nd) Ability not Disability in the Workplace (Leonardo da Vinci project 2009-2011, see: http://www.andiw.isma.lv/.

Latvijas Cilvēku ar īpašām vajadzībām sadarbības organizācija SUSTENTO. ANO konvencija. Rīga: SUSTENTO, available at: http://www.sustento.lv/section/show/ $\underline{35}$ [last accessed 12 January 2011).

Latvijas Statistika (2008) On Poverty and Social Exclusion Indicators Rīga: Centrālās statistikas pārvalde, available at: http://www.csb.gov.lv/en/poverty-and-social-exclusion-indicators [last accessed 12 January 2011].

PwD Employ Partnership Module 2: European Strategies and Policies PwD Employ - Personal Learning Environment for the Efficient Recruitment of People with Disabilities, Leonardo da Vinci project, 2008-2010, http://www.pwdemployple.net/.

PwD Employ Partnership Module 3: Legal Environment, National Strategies and Policies PwD Employ - Personal Learning Environment for the Efficient Recruitment of People with Disabilities, Leonardo da Vinci project, 2008-2010, http:// www.pwdemploy-ple.net/. 